BLACK, M., 1934. In A Synopsis of the Jurassic Rocks of Yorkshire. III. The Middle Jurassic Rocks. Proc. Geol. Assoc., xlv, 261.

Fox-STRANGWAYS, C. The Jurassic Rocks of Britain: Vol. I-Yorkshire. Mem. Geol. Surv.

Kendall, P. F., and WroOt, W. E., 1924. The Geology of Yorkshire. Leeds.

MorrIs, J., 1853. On Some Sections in the Oolitic district of Lincolnshire. Quart. Journ. Geol. Soc, ix, 317.

Simpson, M., 1868. A Guide to the Geology of the Yorkshire Coast (Fourth Edition), pp. 36-40, Whitby.

\title{
CORRESPONDENCE
}

\section{INDEX FORAMINIFERA OF THE CHALK}

SIR,-Considerable research has been undertaken during the last few years, particularly by petroleum geologists, to establish zonal indices among the foraminifera of the Chalk of England, Sweden, and North Germany. The English Chalk has been studied by E. Williams-Mitchell and the Swedish by Dr. F. Brotzen, while at least six workers, Altaner, Bettenstaedt, Hiltermann, Olbertz, Wedekind, and Wicher, have made valuable contributions towards this subject in North Germany. The results of all these studies are now available in published form.

The Anglo-Iranian Oil Company, London, have received from Dr. O. Heermann, of the Deutsche Vacuum Oil Company, the gift of a topotype set of some of the material from borings at Cuxhaven and Siegfried, consisting of named and mounted index species of each zone from the Turonian to the Maestrichtian.

In order that this material may be available to students the Company have decided to present it to the British Museum (Natural History), where Mr. C. D. Ovey is gradually building up a collection of Mesozoic and Tertiary material, his ideal being to accumulate as complete a stratigraphical sequence as possible, solely for the purpose of studying the microfauna zonally and biologically. Both from this aspect and from the fact that many important type collections, including F. Chapman's and Williams-Mitchell's Chalk specimens are preserved there, the Cuxhaven and Siegfried material is obviously an enhancement.

\section{Anglo-Iranian OIl Company.} 10 th November, 1948.

\section{A. G. Davis.}

\section{THE TERM "MAGMA-TYPE"}

SIR,-In their recent paper " On Magma-Types and their Nomenclature" (Geol. Mag., 1948, p. 349) Mr. M. K. and Dr. A. K. Wells seem to be straining at a couple of inoffensive gnats whilst swallowing with relish a particularly monstrous camel. I am grateful to my two friends for providing me with a suitable opportunity for making a protest-long overdue-against the use and misuse of the term "magma-type". Far too many petrologists have fallen into the habit of speaking of "magma-types ", or even of " magmas", when they simply mean rocks. Scientific jargon, appropriate to the circles in which it is understood, cannot be altogether avoided, but this particular example is so definitely unscientific and mischievous that it has become a positive danger.

Defined objectively, a so-called " magma-type" is the mean of a number of chemical analyses of rocks (of igneous or supposedly igneous origin) so similar in composition that the deviation of each constituent from its mean 
value is small. By a natural extension of associative meaning the term is commonly applied to any member of a class of rocks so characterized. The term itself, however, is a complete misnomer, because it inevitably carries with it the implication $(a)$ that the rocks concerned have crystallized either from a common magma or from magmas of closely similar composition, and $(b)$ that the composition of the parental magma or magmas corresponds approximately to that of the rocks from which the type is abstracted. How serious the resulting confusion of thought can become is illustrated on p. 349 of the paper under consideration, where the authors state that a "magmatype " "was meant to be only a little different from a "rock magma ".

The real conception behind the term is one of similar composition and, in itself, it has not necessarily anything to do with magmas. In a word, a "magma-type" is not a type of magma ; it is a statistical concept. But composition alone rarely serves to discriminate between different modes of origin. Yet the term implies by its verbal tyranny that the mode of origin of the class of rocks concerned is already known, and that it is indisputably magmatic. Recognition of the real problems of petrogenesis thus tends to be inhibited by the hypnotic spell of an unduly generalized hypothesis for which genuine supporting evidence can be found in only a few rather obvious cases. The authors of the Mull Memoir were admittedly dealing for the most part with one of these more obvious cases, but this excuse cannot be made for others-I am thinking especially of Niggli and Billings-who have made the term a real menace to understanding and progress by extravagantly applying it to hosts of classes of rocks for which a magmatic origin has never been demonstrated.

Another example of a term which embodies a hypothesis as if it were an established fact is " Comagmatic". Judd's "Petrographic Province" is a straightforward descriptive term that raises a most intriguing problem without presuming to prejudge the issue. Washington's "Comagmatic Region " hides the problem by implying a hypothetical solution in advance. The potash-rich volcanic rocks adjoining Ruwenzori in S.W. Uganda constitute a highly individualized petrographic province, but I have so far been unable to demonstrate that they are "comagmatic ". I mention this case because I cannot agree that the rocks concerned illustrate what Wells and Wells (p. 350) call a good example of a " magma-type ". The remarkable geochemical peculiarities of the rocks point to a high degree of consanguinity, ${ }^{1}$ but their complex heredity has been so much modified by the effects of environment that no satisfactory genealogy can, as yet, be disentangled.

Petrological terms, both in form and definition, should as far as possible be purely descriptive and free from hypothetical petrogenetic implications. 1 feel very strongly that of all the many terms that fail in this respect " magmatype "and "comagmatic" are amongst the most unwarranted and the most dangerously misleading. In place of " magma-type " an objective term such as "composition-type" would adequately convey all that is needed.

As to the "gnats" of my opening sentence, I have not found in practice that the terms "olivine-basalt " and " tholeiitic" give rise to any ambiguities when used in their proper context. The proposed alternatives, however, fail to suggest-to me, at any rate - the right associations. "Simatic" suggests rocks of unknown, but probably ultrabasic composition, and is therefore too broad and ambiguous for a "type" name. "Sub-sialic" embodies a hypothesis ; "sub," moreover, suggests olivine to followers of Shand's nomenclature, whilst " sialic" distracts attention from the idea of basaltic composition; the term is therefore inappropriate.

Grant Institute of Grology,

ARTHUR Holmes.

UNIVERSTTY OF EDINBURGH.

15th December, 1948.

1 It should be pointed out that this term was not coined by Harker, as stated on p. 355, but was first adopted in a petrogenetic sense by Iddings (see Harker's Natural History of Igneous Rocks, p. 89). 